\title{
Application of Seawater Plant Technology for supporting the Achievement of SDGs in Tarawa, Kiribati
}

\author{
Mi-Yeon Choi, Ho Ji, Ho-Saeng Lee, Deok-Soo Moon, Hyeon-Ju Kim ${ }^{\dagger}$ \\ Seawater Energy Plant Research Center(SEPRC), Korea Research Institute of Ships \& Ocean Engineering(KRISO), \\ Goseong 24747, Republic of Korea
}

\section{키리바시 타라와의 지속가능발전목표 달성 지원을 위한 해수플랜트 기술 활용}

\author{
최미연, 지호, 이호생, 문덕수, 김현주 \\ 선박해양플랜트연구소 해수에너지연구센터, 24747, 강원도 고성군 죽왕면 심층수길 124-32
}

\begin{abstract}
키리바시를 포함한 태평양 도서국가들은 기후 변화, 지하수 오염 및 식생 변화로 인한 해수면 상승 및 해안 침식으로 인해 생활 공간의 감소 뿐만 아니라 필수 자원 부족으로 고통받고 있다. 이러한 문제를 해결하기 위한 글로벌 활동은 $\mathrm{SDGs}$ 이행을 위한 UN의 노력으로 진행되고 있다. 태평양 도서 국가들이 풍부한 해양 자원을 이용하여 기후 변화에 대응하고 적응할 수 있도록 모색해 왔다. 즉, 해수 플랜트는 이러한 태평양 도서 국가에서 SDG \# 14를 기반으로 SDG \#2, \#6 및 \#7을 달성하는 데 도움을 줄 수 있다. 선박해양플랜트연구소(KRISO)는 2016년에 설립한 지속가능 해수이 용 아카데미(SSUA)를 통해 키리바시 SSUA협회를 결성하고, 해양수산부(MOF)의 해양수산 ODA사업으로 키리바시에 해수플랜트를 지원하였다. 키리바시 SSUA협회는 해수 및 태양에너지를 이용하는 해수플랜트를 이용하여, 2018년부터 2020년까지 지역 사회에 식수와 채소를 공급하는 공익사업을 하고 있다. 역량강화 과정을 통해 키리바시 SSUA협회는 기술 이전을 받았고, 지역사회에 수경재배 시스템의 설치, 모종과 비료 보급, 재배관리 기술지도 및 모니터링을 실시 하였다. 협회는 3 년 동안 140 여 가구에 수경재배 시스템(일부는 태양광발전 패널 제공)을 보급하고, 다양한 채소를 재 배하여 자가 소비 또는 판매하게 하였다. 또한, 태양광발전 연계 해수담수화 시스템을 설치하여 식수를 공급하도록 하 고 있다. 만족도 조사를 통해 대부분의 수혜 가구가 만족하였고, 주변 지역 및 도서로 보급확산을 희망하고 있음을 알 수 있었다. 따라서, 키리바시 SSUA협회는 공동체 이용 및 관리 체계화를 지원하는 자활사업을 추진할 계획이며, 이러 한 활동은 태평양 도서국가들의 SDGs 달성을 지원하기 위한 ODA 프로그램으로 확산될 수 있을 것이다.
\end{abstract}

Pacific island countries, including Kiribati, are suffering from a shortage of essential resources as well as a reduction in their living space due to sea level rise and coastal erosion from climate change, groundwater pollution and vegetation changes. Global activities to solve these problems are being progressed by the UN's efforts to implement SDGs. Pacific island countries can adapt to climate change by using abundant marine resources. In other words, seawater plants can assist in achieving SDGs \#2, \#6 and \#7 based on SDGs \#14 in these Pacific island countries. Under the auspice of Korea International Cooperation Agency (KOICA), Korea Research Institute of Ships and Ocean Engineering (KRISO) established the Sustainable Seawater Utilization Academy (SSUA) in 2016, and its 30 graduates formed the SSUA Kiribati Association in 2017. The Ministry of Oceans and Fisheries (MOF) of the Republic of Korea awarded ODA fund to the Association. By taking advantage of seawater resource and related plants, it was able to provide drinking water and vegetables to the local community from 2018 to 2020 . Among the various fields of education and practice provided by SSUA, the Association hope to realize hydroponic cultivation and seawater desalination as a self-support project through a pilot project. To this end, more than 140 households are benefiting from 3-stage hydroponics, and a seawater desalination system in connection with solar power generation was installed for operation. The Association grows and supplies vegetable seedlings from the provided seedling cultivation equipment, and is preparing to convert to self-support business from next year. The satisfaction survey shows that Tarawa residents have a high degree of satisfaction with the technical support and its benefits. In the future, it is hoped that SSUA and regional associations

${ }^{\dagger}$ To whom correspondence should be addressed.

E-mail: hyeonju@kriso.re.kr

Received: 29 September 2021, Revised: 26 October 2021, Accepted: 27 October 2021 
will be distributed to neighboring island countries to support their SDGs implementations.

KEYWORDS: SSUA(Sustainable Seawater Utilization Academy), Seawater plant, Hydroponics, PV-RO Desalination system, Capacity building, ODA(Official Development Aids)

\section{Introduction}

키리바시는 기후변화에 따른 수몰 위험뿐만 아니라 생존 필수자원인 식량(Food), 에너지(Energy) 및 식수(Water)가 부족하여 고통받고 있는 대표적인 기후재해 도서국가이다. 해수면 상승으로 인하여 해수가 침투하여 토지 면적이 급 감하였고, 농산물 생산도 타격을 받고 있다. 잦은 가뭄으로 인하여 물 부족도 심화되고 있다(https://en.wikipedia.org/ wiki/Kiribati, 2021). 따라서, 채소 등의 식품원료를 호주, 뉴 질랜드 등으로부터 수입하므로 가격이 비싼 편이다. 평균 가 구 수입의 $46 \%$ 가량을 식량 구입에 소비하고 있는 실정이 다. 또한 만 10 세 이하의 아이들 중 $20 \%$ 이상이 영양실조 를 겪고 있으며(WHO 2015), 영양 불균형으로 인해 당뇨를 앓고 있는 성인들의 비율은 2014년, $22 \%$ 에서 계속 증가하 는 추세이다(WHO 2016). 또한 전력 수요의 약 $10 \%$ 를 신 재생에너지로 충당할 뿐 대부분 디젤 발전에 의존하고 있 으며, 에너지 공급률은 $48.3 \%$ 에 불과한 실정이다. 대부분의 시민들은 빗물을 모아서 생활용수로 이용하고, 이를 정수하 여 식수로 사용하고 있으나 강수량이 불규칙하여 식수난을 겪고 있다. 지하수는 PUB (Public Utility Board)가 지하 수 도를 통해 각 마을마다 공급하는데, 염수 침입과 가뭄으로 인해 지하수 저장량이 감소하여 일주일에 48시간만 제한 급 수를 실시하고 있다. 호주, 피지, 대만 등에서 먹는 물을 수 입하고 있으나 $1.5 \mathrm{~L}$ 의 평균 가격이 호주달러 1.5 달러 이상 이어서 시급 호주 3 달러 미만을 받고 있는 일반 주민들이 이를 구입하는 것은 쉽지 않다. 안전한 식수 및 위생이 보장 되는 환경에서 사는 인구는 $50 \%$ 이하이며(UN 2008), 태아 사망률이 $6.6 \%$ 이상으로 매우 높은 것으로 알려지고 있다. 이러한 문제를 해결하기 위한 글로벌 활동은 SDGs 이행 을 위한 UN의 노력으로 진행되고 있다. 태평양 도서 국가 는 풍부한 해양 자원을 사용하여 기후 변화에 적응할 수 있 다. 즉, 해양온도차발전, 해수담수화시스템 등의 해수 플랜 트는 태평양 도서 국가에서 SDG \# 14(해양생태계 보존)를 기반으로 SDG \# 2(기아종식), \# 6(깨끗한 물과 위생) 및 \# 7(저렴하고 깨끗한 에너지)을 달성하는 데 도움을 줄 수 있 다(Petterson and Kim, 2020).

해수자원을 이용하여 식수, 에너지 및 식량을 안정적으로 공급할 수 있도록 돕기 위한 해수플랜트 기반의 ODA 프로

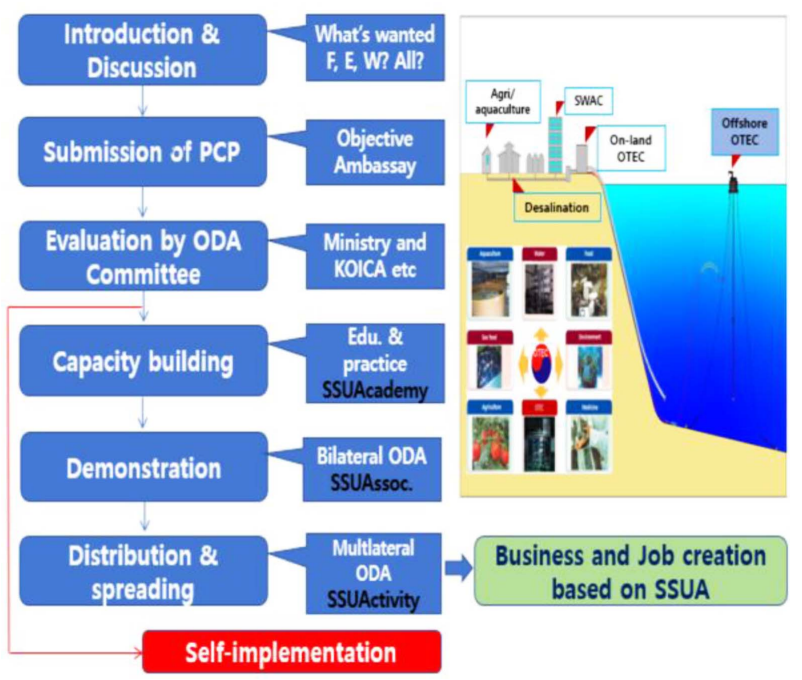

Figure 1. Framework of OK-ODA for Sustainable Seawater Utilization Technology

그램 체계가 Figure 1과 같이 정립되었다(Kim et al., 2018; Kim, 2021).

한국국제협력단(KOICA)의 후원으로 선박해양플랜트연 구소(KRISO)는 2016년에 지속 가능한 해수 이용 아카데미 (SSUA, Sustainable Seawater Utilization Academy)를 설립하 였다(Choi et al., 2020). SSUA 협회는 APP1-1(민관협력사 업)로 추진하였던 '키리바시 해수온도차발전 배출수의 다목 적 이용 모델 및 타당성 평가'의 역량 강화 교육의 수혜자 들이 2017년에 자발적으로 구성한, 정부(여성부; Ministry of Women, Youth and Social Affairs)로부터 인정받은 비영리 기 관(NGO)이다. 협회는 키리바시 공무원, 남태평양대학교 (University of South Pacific), 키리바시기술대학교(Kiribati Institute of Technology), 타라와 섬 마을 이장 등 총 23명으 로 이루어져 있으며, 미국, 피지 및 미국 전문가들과 정보 교류 및 파트너쉽 유지하고, 자체적으로 지속가능한 식수 및 식량 생산 기반 확보를 통한 기후변화 대비를 위해 설립되 었다. 이들은 기후변화에 적응하기 위한 해수의 다목적 이 용(담수화, 수경재배, 해조류양식, 해수냉난방 등) 관련 프로 젝트 구상 및 실행을 지원한다.

선박해양플랜트연구소는 2017년 3월 키리바시 정부(인프 라에너지부, Ministry of Infrastructure and Sustainable Energy) 
로부터 해수 담수화 시설 및 수경재배시스템의 지원을 요 청 받아, SSUA 협회와 함께 2018년부터 2020년 까지 키리 바시 ODA 사업을 추진하여 키리바시 해수를 이용한 식수 및 식량생산시스템을 구축하였다. 따라서 본연구에서는 키 리바시 ODA 사업의 수행 내용과 성과를 소개하고자 한다.

\section{키리바시 현황}

\section{1. 사회경제 현황}

키리바시(Kiribati)는 오세아니아에 있는 적도 근처의 섬 나라이다. 국토 면적은 $811 \mathrm{~km}^{2}$ 이며, 2017년 기준 인구는 116,400 명이다. 국가 GDP는 $\$ 180$ million이며, 1인당 GDP 는 $\$ 1,685$ 로 낮은 편이다. 인구의 절반이 수도인 타라와 (Figure 2, Tarawa, 북위 $1^{\circ} 26^{\prime} \mathrm{N}$, 동경 $173^{\circ} 00^{\prime} \mathrm{E}$ )에 거주하고 있고, 면적은 $500 \mathrm{~km}^{2}$ 에 불과하여 인구밀도가 매우 높은 편 이다. 타라와는 높은 곳의 해발고도는 $3 \mathrm{~m}$ 에 불과하고, 해수 면 상승 및 해안 침식으로 위협받고 있다.

타라와는 바다에서 잡을 수 있는 어패류와 코코넛열매 말 고는 천연자원이 많지 않다. 농지와 용수가 부족하여 농산 물 배양이 어려운 상황이다. 수입해오는 쌀과 근처에서 잡 은 생선을 주식으로 먹지만, 채소와 과일이 부족한 실정이 다. 어려서부터 설탕물을 먹기 때문에 많은 아이들이 당뇨 등 영양 불균형으로 인해 질병에 시달리고 있다.

따라서, 높은 인구 밀도를 고려할 때, 부족한 물과 채소 를 안정적으로 공급하는 것이 지역 사회를 위한 중요한 사 회경제적 과제이다.

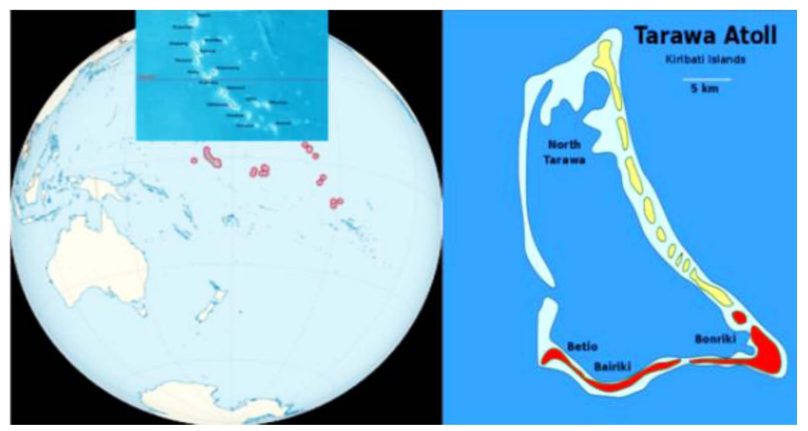

Figure 2. Location of Tarawa, Kiribati (https://en.wikipedia.org/wiki/Kiribati, 2021; https://commons.wikimedia.org, 2021)

\section{2. 자연 환경}

키라바시 타라와 지역의 기온은 연평균 $31^{\circ} \mathrm{C}$ 이며, 최고 $37^{\circ} \mathrm{C}$ 에서 최저 $27^{\circ} \mathrm{C}$ 로 연간 및 일간 변동하는 것으로 조사 되었다. 연평균 외기 온도는 주간 $31.4^{\circ} \mathrm{C}$ 로 나타나며, 야간 $25.3^{\circ} \mathrm{C}$ 로 나타났다(Figure 3). 상대습도는 최대 $100 \%$, 최소
$19 \%$ 로 조사되었다. 일 최대 강수량은 $68.6 \mathrm{~mm}$ 이며, 연평균 강수일수는 154 일에 달하였다. 월 최대 평균 풍속은 $16 \mathrm{~km} /$ $\mathrm{h}$ 였고, 순간최대풍속은 $47 \mathrm{~km} / \mathrm{h}$ 로 조사되었다. 파고는 $2 \mathrm{~m}$ 이상이 내습할 때도 있지만 연평균 파고는 $1 \mathrm{~m}$ 로 알려져 있 다. 타라와의 시설들은 자연재해에 충분히 대비하지 않고 있 어 보이며, 대조기와 고파랑 내습이 겹치는 경우에는 연안 침식뿐만 아니라 침수 피해가 심각하게 발생하기도 한다 (Figure 4). 타라와는 산호섬으로 인구가 밀집한 지역의 주 변은 산호가 많이 죽어 있으며, 인구가 적은 지역 주변은 잘 보존되어 있는 것으로 알려지고 있다. 최근에는 산호초 표 백현상으로 인해 천해역에서의 잡는 어업은 기피하고 있으 며, 깊은 바다로 나가서 어로활동을 하고 있다. 담수가 부 족하여, 빗물을 모아서 생활용수로 이용하고, 이를 정수하 여 식수로 사용하고 있다(Figure 5). 강수는 매월 있지만 1

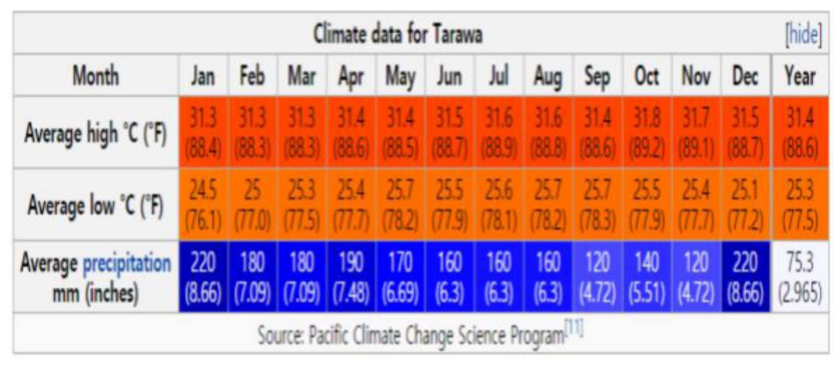

Figure 3. Monthly temperature and precipitation in Tarawa, Kiribati (https://en.wikipedia.org/wiki/Kiribati, 2021)

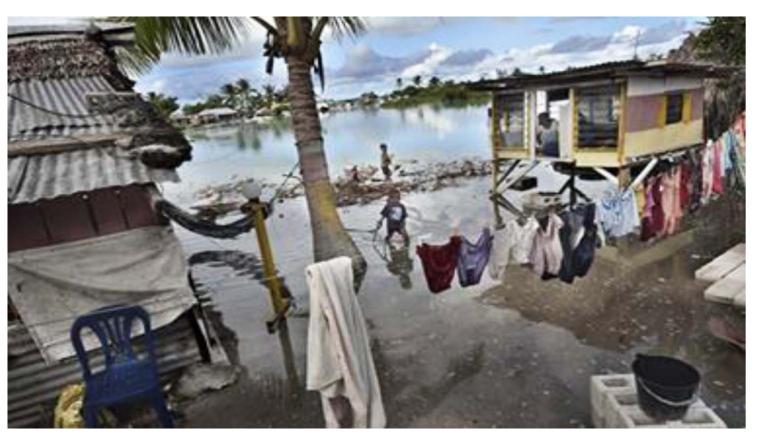

Figure 4. Rising sea level in Kiribati flooded agricultural and residential areas

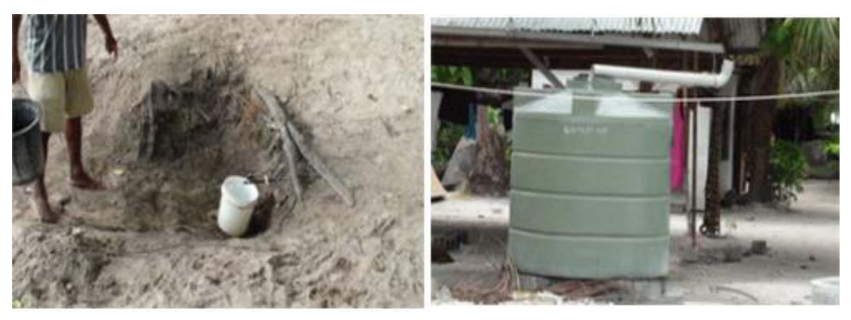

Figure 5. Depleted groundwater and rainwater tank to secure water in Kiribati 
월에 가장 많이 오고, 9 월에는 적은 편이다. 이러한 자연 환 경을 통해 타라와는 삶의 질 제고를 위해 냉방 뿐 아니라 식수도 필요한 상황임을 알 수 있다.

따라서, 풍부한 자연에너지와 바닷물을 이용하여 담수를 확보하고, 수경재배에 활용함으로써 지속가능성을 보장하 는 역량강화가 필요하다.

\section{해수를 이용한 식수 및 식량생산 시스템 지원}

인구 밀도가 높은 키리바시 타라와가 겪고 있는 기후변 화와 해안침식에 의한 식수 부족과 과채류 재배의 한계를 해소하기 위하여 제안된 해양수산 ODA 사업은 해양수산부 로부터 약 7억원의 예산을 지원을 받아 2018년 6월부터 2020년 12월까지 수행되었다. 선박해양플랜트연구소(KRISO) 가 주관하고, 강원대학교, 키리바시 SSUA 협회, 에너지인 프라부(MISE, Ministry of Infrastructure and Sustainable Energy), 환경토지농업부(MELAD, Ministry of Environment, Land and Agriculture Development), USP(The University of the South Pacific) 가 참여하였다. 키리바시 SSUA 협회는 기 술 이전을 받아서 참여 가구 모집, 교육 및 실습, 보급 및 설치 지원, 수혜자 만족도 조사 등을 담당하였다.

본 프로젝트는 키리바시 수도인 타라와 지역의SDGs 해 당목표인 \#6(깨끗한 물과 위생), \#2(기아 종식) 및 \#7(저렴 하고 깨끗한 에너지)를 달성하도록 지원하고자 한 것이다. 이 를 위해, 해수 수경재배 기술과 해수미네랄 및 영양염 추출 및 양액 생산 기술, 그리고 신재생 해수담수화시스템의 설 치 및 운영 기술을 교육 및 실습을 통해 이전하고, SSUA 협 회가 보급확산의 주체로서 전문가로 양성되도록 하는 것이 다(Kim, 2021).

2018년에는 수경재배 시스템 보급을 통한 현지의 식량(식 품원료) 공급, 2019년에는 신재생 해수담수화 설치를 통한 식수 문제 완화, 2020년에는 사후 모니터링 및 현지 자활사 업 전환을 위한 교육 및 지원을 실시하였다.

\section{1. 수경재배 시스템 보급}

수경재배는 육상식물을 토양없이 양액을 첨가한 물을 순 환 공급하여 키우는 방식이다. 박막 재배식 수경재배는 재 배필드 내에 양액이 고이지 않고 바닥에 수막을 형성하며 흘러가는 방식으로, 포트의 난석이 양액을 흡수해 식물에 영 양을 공급하는 방식이다. 양액을 최소한으로 사용 가능하여 물이 부족한 키리바시에서 사용하기에 적합한 방식이며, 식 물 뿌리가 최대한 공기에 노출되어 산소호흡이 원활하게 되 므로 왕성한 식물성장을 이끌어낼 수 있다. 토양의 질이 악 화된 지역이나 작물을 키우기 힘든 지역에서도 신선한 농
작물의 생산을 가능하게 한다. 따라서 키리바시에 보급할 박 막재배식 수경재배 시스템은 '참쉬운수경재배' 업체에서 제 작한 하이드로가든 행거킷 3 단의 모델로 선정하였다(Figure 6). 이는 높이 $1.6 \mathrm{~m}$, 길이 $1.05 \mathrm{~m}$, 폭 $0.43 \mathrm{~m}$ 이며, 재배포트는 48 구이며, 52 리터의 수액기(통)에서 $20 \mathrm{~W}$ 의 순환펌프를 이 용하여 주기적으로 수분과 양액을 공급하는 구조로 구성되 어 있다.

수경재배시스템의 보급은 2018년도와 2019년도에 이루 어졌다(KRISO, 2018; KRISO, 2019). 2018년 6월에 현지에 방문하여 SSUA 협회 회원을 대상으로 수경재배 이론 및 육 묘 및 재배 실습교육을 진행하였다(Figure 7). 교육용 수경 재배시스템 2세트를 SSUA 협회에 제공하여 수경재배 통기 성 확보 실험 등을 자체적으로 진행하게 하였다. 8 월 말에 는 수경재배시스템 100 세트와 종자 보급을 위한 씨앗 발아 베드 시스템 1개를 컨테이너에 실어 현지 배송하였다. 9월 부터 SSUA 협회에 의해 현지 지역 주민에게 보급하였다 (Figure 8). SSUA협회의 고문을 맡고 있는 USP 교수 출신 인 농학자 토핑가 박사(Dr. Mareko Tofinga)가 중심이 되어 현지의 재료를 이용한 배지 제작, 비료 첨가율 및 성능 비 교, 다양한 과채류에 대한 작물 재배 등을 실험 및 실습을 통해 수행하면서 역량 강화가 이루어졌다. 12월에는 현지에 방문하여 그동안 보급된 수경재배시스템을 이용하여 재배 한 가구 중 우수 농가 20가구를 선정하여 수경재배용 태양 광발전 패널 및 배터리를 포상으로 제공하였다.

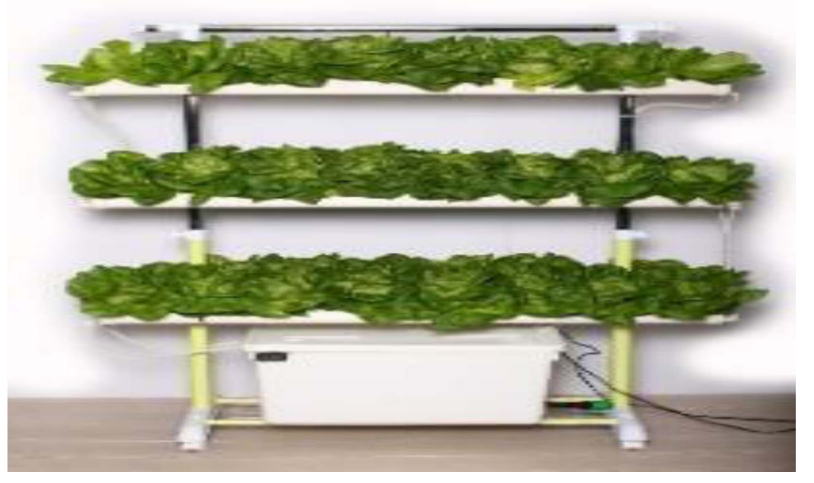

Figure 6. Hydroponic system for Vegetable cultivation

이후 현지 SSUA 협회로부터 수경재배 시스템을 보급 받 지 못한 가구들이 수경재배 시스템을 보급 받고자 희망한 다는 내용을 전달해 왔다. 현지의 부족한 농지를 사용하지 않고 생산성이 뛰어나며, 부족한 과채류 작물을 자급할 수 있기 때문에 반응이 좋았다고 한다. 협회 뿐만 아니라 키리 바시 정부(환경농업부, MELAD) 도 추가 지원과 타 지역 보 급을 요청해 왔다. 또한 수경재배 순환펌프 가동을 위한 전 력 공급을 위한 태양광발전 패널에 대해 추가 요청이 있었 
다. 이에 2019년 11월에 수경재배시스템과 태양광발전 패 널 40세트를 추가로 보급하였다.

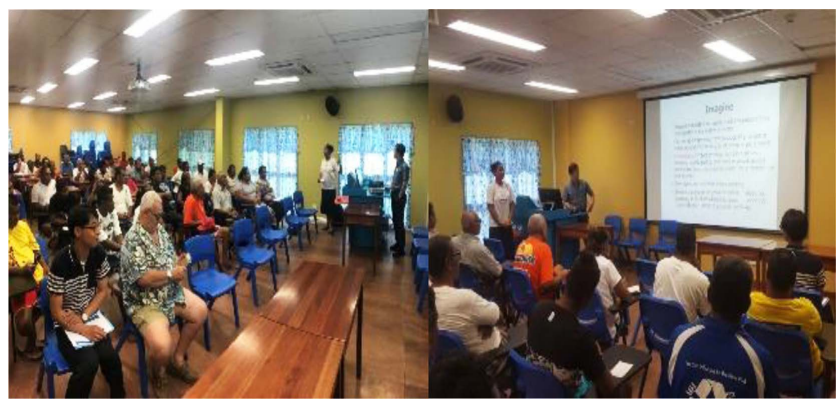

Figure 7. Hydroponic cultivation education in June 2018

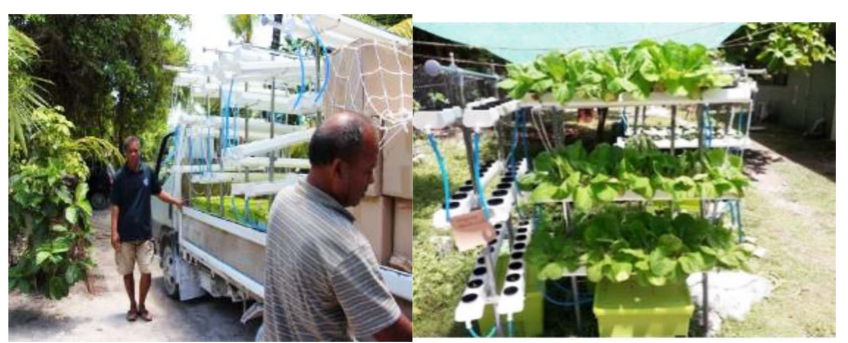

Figure 8. Supply and cultivation of hydroponic system

수경재배시스템의 보급 및 교육, 재배 현황에 대한 모니 터링은 SSUA 협회를 통해 진행되었다. SSUA 협회 회원 1 인당 10 가구를 담당하여, 모종 및 비료 보급, 재배 및 관리 지도, 수확 및 이용, 문제점 파악 및 개선 조치 등을 모니 터링 하고 월별 보고서를 작성하였다.

그 결과로서 타라와 지역에 대한 보급 현황을 Figure 9에 나타내었다. 타라와 지역의 Bariki 마을 19가구, Nanikai 마 을 6가구, Teaoraereke 마을 15가구, Korobu 마을 8가구, Ambo 마을 21가구, Banraeba 마을 9가구, Betio 마을 14가 구, Bikenibeu 마을 8가구에 보급되었다. 또한, 키리바시 인 프라에너지부(MISE), 환경농업부(MELAD), 에너지공사 (PUB) 등의 관공서 및 도로변에 위치한 호텔에도 전시홍보 목적으로 2기씩 제공하여 2018년에 100세트의 수경재배 시 스템이 보급되었다. 2019년 이후에는 SSUA 협회를 통해 Taborio 마을 20가구와 Tanaea 마을 20가구에 보급이 이루 어져 총 140 세트의 수경재배시스템이 타라와에 보급되었다. 2020년에는 수경재배시스템의 추가 보급뿐만 아니라 SSUA 협회의 모니터링 및 자활 사업으로 전환을 위한 자 체 실험 및 교육이 이루어졌다(KRISO, 2020). 채소의 성장 과 수확량 향상을 위한 비료의 사용 및 생장속도 비교 실 험이 진행되었고, 작물의 다양성 확보를 위한 타 종자 재배 실험도 진행되었다. 실험 결과를 바탕으로 협회가 가정을 방
문하여 교육 및 지도를 수행하고 지속적인 수경재배시스템 의 유지 및 이용이 가능하도록 하였다. 또한, SSUA 협회는 USP 키리바시 캠퍼스와 함께 수경재배에 대한 자격증을 제 공하는 대규모 교육과정을 준비 중이다.

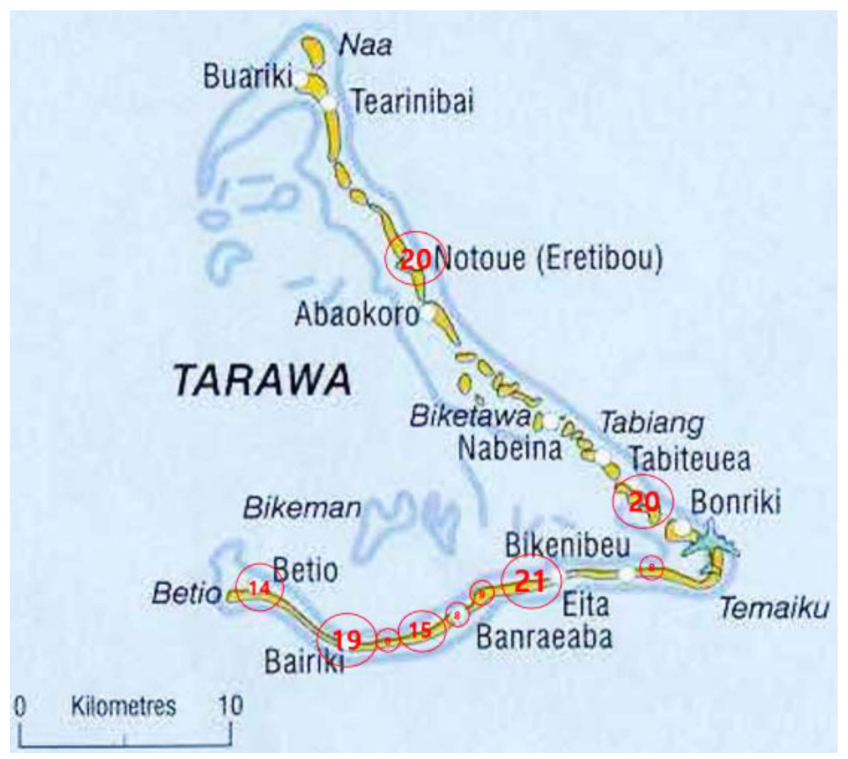

Figure 9. Location and number of households at recipient villages along Tarawa (https://en.wikipedia.org/wiki/Kiribati, 2021)

\section{2. 태양광발전 연계 해수담수화시스템 보급}

키리바시에 식수 생산 시스템을 지원하기 위한설치 장소 는 키리바시 정부와 협의를 거쳐 Tanaea 마을의 MELAD 부 지를 활용하기로 협의하였다(Figure 10). 설치 대상지는 내 만과 외해를 연결하는 해수로가 있어서 간조 시에도 상시 해수 취수가 가능하고, 취수거리도 $50 \mathrm{~m}$ 이내로 가깝기 때 문에 적합하였다.

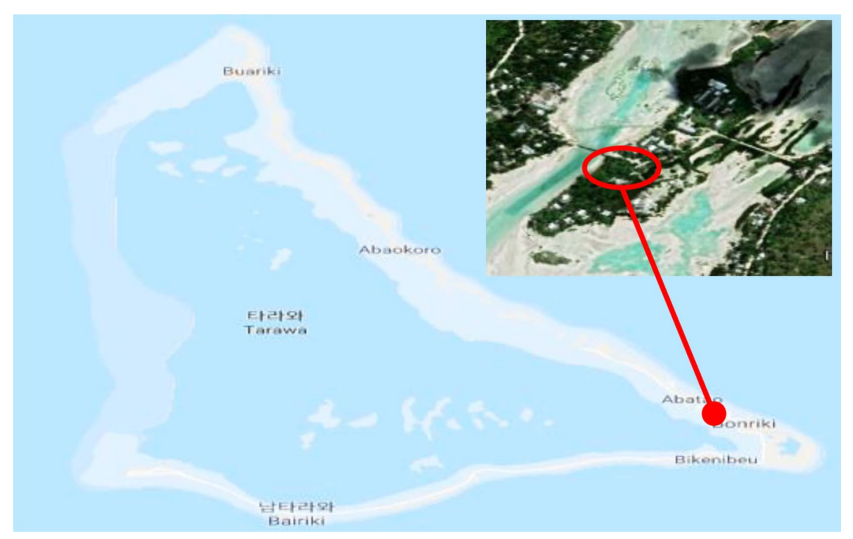

Figure 10. Installation site of solar powered seawater desalination system (Tanaea, Kiribati) 

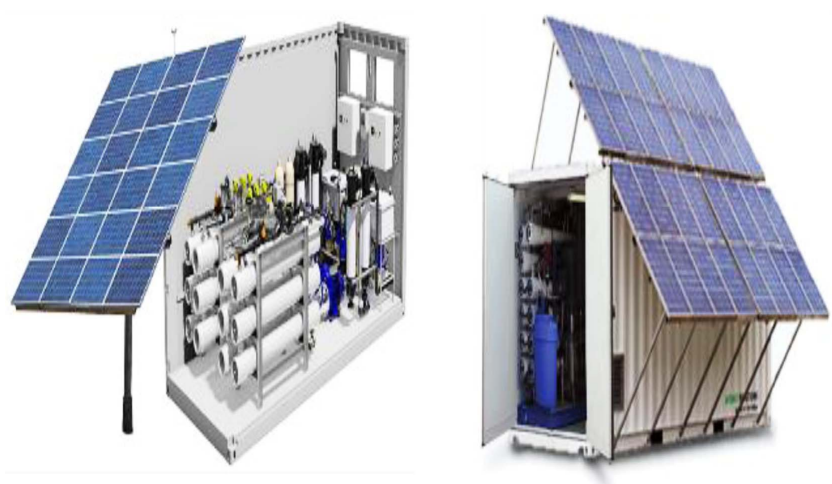

Figure 11. Concept of solar powered seawater desalination system

태양광발전 연계 해수담수화시스템을 설계하여, (주디지 워텍을 통해 제작하였다. $10 \mathrm{~m}^{3} / \mathrm{day}$ 의 담수(식수) 생산이 가 능한 역삼투식 담수화 장치를 5 개의 RO막과 샌드필터 및 $\mathrm{MF}$ 여과막 2개, UV 살균기로 구성하였다. 태양광발전 패널 은 RO설비를 탑재한 컨테이너 지붕에 구축하기로 하였다 (Figure 11).

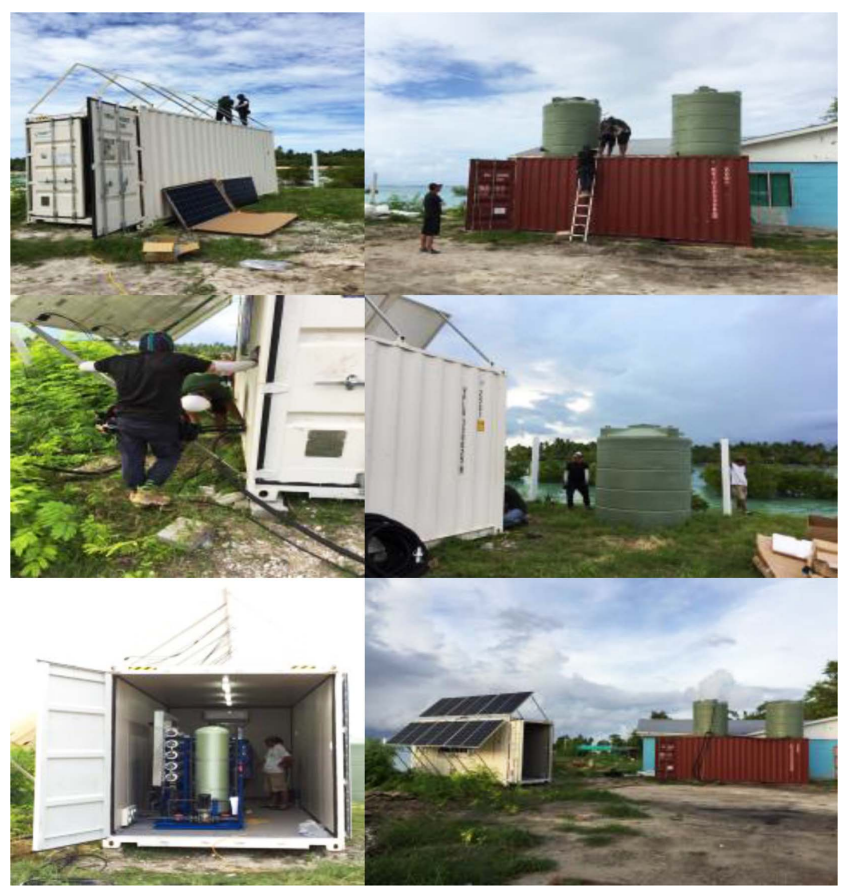

Figure 12. Installation of solar powered seawater desalination system

태양광발전 연계 해수담수화시스템은 2019년 11월에 현 지 방문을 통해 진행되었다(Figure 12). 해수담수화시스템의 사용 및 관리를 위한 MELAD와 SSUA협회 간의 MOU도 진 행되었다. 또한 SSUA 협회 회원 및 관계 부처 공무원을 대 상으로 태양광발전 연계 해수담수화시스템의 운전, 유지 및
관리에 대한 교육을 진행하였다(Figure 13). 태양광발전 연 계 담수화시스템의 원리, 취수관 연결, 해수펌프 작동, $\mathrm{RO}$ 담수화시스템의 원리 및 작동, $\mathrm{RO}$ 막 교체 방법 등에 대한 교육을 실시하였다.

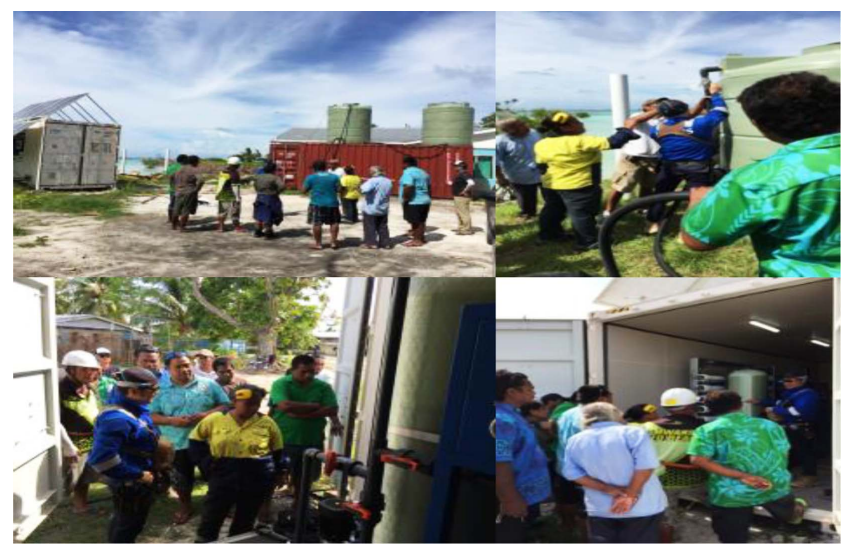

Figure 13. Operation method and maintenance training of solar complex desalination system

2020년에는 현지 방문을 통해 해수담수화시스템의 가동 및 식수 공급을 진행하려고 하였으나, COVID-19 사태로 인 해 키리바시 입국이 불가하여 SSUA 협회가 자체적으로 운 전 및 관리가 가능하도록 원격 교육 및 지원을 실시하였다. 식수 보급을 협회의 자활 사업으로 전환하기 위한 운영 및 관리 교육 영상을 제작하였다(Figure 14)(KRISO, 2020).

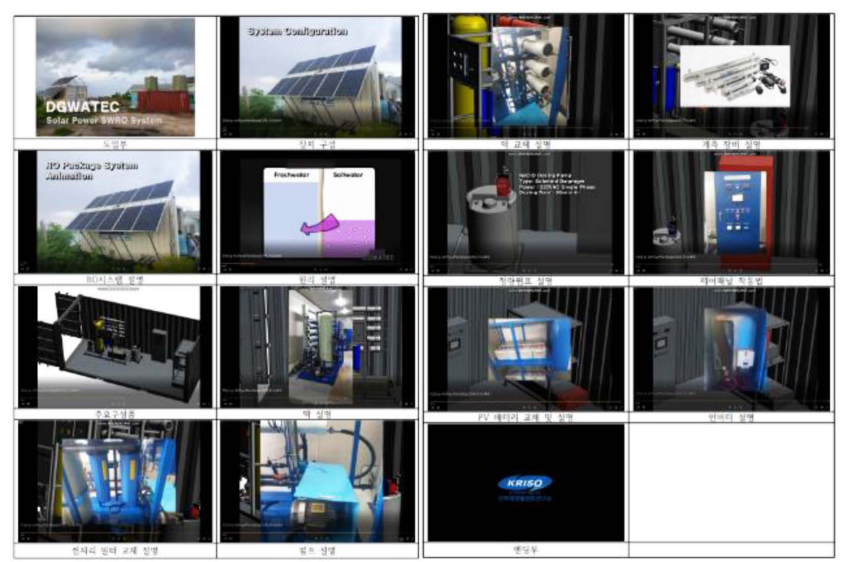

Figure 14. Educational video of solar powered seawater desalination system

\section{3. 만족도 조사}

키리바시 정부와 SSUA 협회는 2018년부터 2020년까지 실시한 수경재배시스템의 보급 사업에 대한 점검 및 개선 을 위하여 수혜 가정을 대상으로 만족도 조사를 시행하였 
다. 설문지 내용은 1) 재배한 채소의 종류, 2) 생산 횟수 및 생산량, 3) 사용 방법(자가 소비, 이웃 공유, 판매), 4) 만족 도, 5) 사업 유지 및 확산 필요성, 6) 기타 애로 및 요구 사 항으로 구성하였다(Figure 15).

수경재배시스템을 수령한 140 가구를 대상으로 만족도 조 사를 시행한 결과가 Figure 14,15 에 나타내어져 있다. 주로 재배한 채소는 배추(Chinese cabbage), 양배추(English cabbage), 토마토, 오이, 파프리카(sweet pepper), 수박, 양상추(lettuce), 록 멜론(rock melon), 콩, 체리 토마토였고, 배추와 콩의 생 산성이 좋았던 것으로 나타났다. 연간 수확한 횟수는 1 5회 였고, 생산량은 매회 약 $8 \mathrm{~kg}$ 에서 $100 \mathrm{~kg}$ 까지 다양하였다. 태 양광발전 패널을 이용한 수경재배시스템에서는 4 번 수확에 평균 $500 \mathrm{~kg}$ 씩 수확되기도 하였다. 이는 채소가 부족하고 비 싼 현지 사정상 유의미한 것으로 인식되고 있었다.

생산된 채소는 수혜가구의 $80 \%$ 가 자가 소비하였고, 약 $15 \%$ 는 이웃과 공유하였다. 일부 가구 $(5 \%)$ 는 농산물을 판매 하였다(Figure 15). 자가 소비하는 가구의 일부는 생후 6개 월 이상의 아기에게 수확한 채소를 먹이는 것으로 나타났 다. 키리바시는 신선 채소가 부족하기 때문에 의사들이 유 아에게 섭취하는 것을 권장하기 때문이다.

수경재배시스템의 만족도는 매우 높음 $45 \%$, 높음 $25 \%$, 보 통 $15 \%$, 낮음 $15 \%$ 로 나타났다(Figure 16). 만족스럽지 않거 나 개선이 필요한 부분은 펌프 고장, 씨앗과 모종, 비료의 지급 지연 등을 지적하였다. 수혜자들은 더욱 빈번한 방문 및 서비스(펌프 수리, 모종 및 비료 전달) 제공을 원하였다. 따라서, SSUA 협회는 운송 편의화를 위해 오토바이 2대를 구입하여 운영하고 있다.

코로나로 인하여 태양광발전 및 해수담수화 시스템의 운 반 및 설치가 지연되어 만족도 설문조사에는 포함시키지 못 하였으나 생산수를 수경재배에 활용하면서 유사한 만족감 을 느끼고 있다고 SSUA협회를 전언하였다.

수혜가구의 약 $92 \%$ 는 수경재배 및 담수화 시스템에 만족 하여 타라와의 다른 지역 및 키리바시 다른 도서지방에도

\section{How to use(2018-2020)}

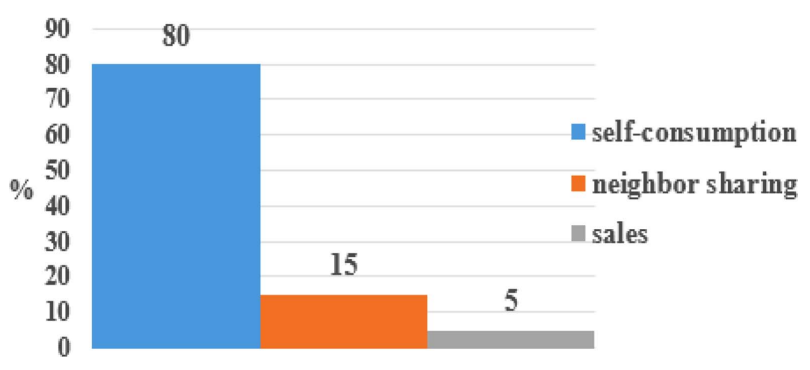

Figure 15. Survey on how to use the of hydroponic Cultivation system

\section{Satisfaction(2018-2020)}

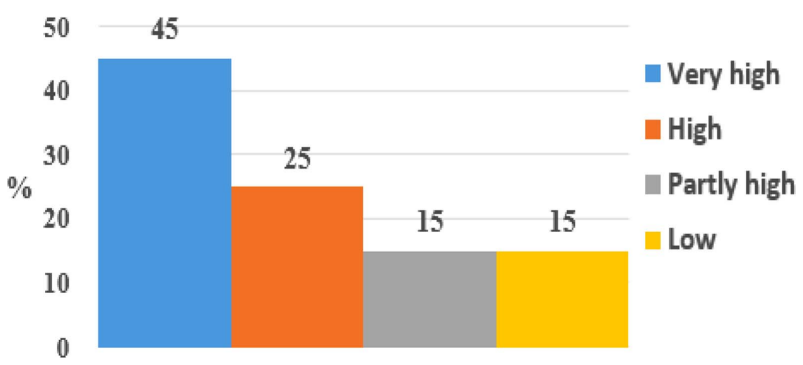

Figure 16. Satisfaction survey on the use of hydroponic cultivation system

보급 확산해 줄 것을 요청하였다. 특히, 응답자들은 태양광 을 이용한 수경재배시스템이 키리바시에 가장 적합하고 이 상적이라고 생각하는 것으로 조사되었다. 수경재배의 지속 적인 유지 및 관리를 위해 '마을위원회'를 구성하여 체계화 하고, 효율적으로 활용하기를 희망하는 것으로 나타났다 (KRISO, 2020).

\section{결론}

선박해양플랜트연구소는 키리바시 SSUA 협회와 함께 2018년부터 2020년까지 키리바시 타라와 지역에서 해양수 산 $\mathrm{ODA}$ 사업을 실시하였다. 이는 수경재배시스템의 보급 과 태양광 복합 담수화시스템의 설치를 통해 지속가능발전 목표(SDGs) \#2와 \#6 및 \#7의 달성을 지원하기 위한 것이었 다(Petterson et al., 2021).

키리바시 SSUA협회는 3년간 140가구에 수경재배시스템 및 태양광발전 패널을 보급하고, 1 일 10 톤의 식수를 생산할 수 있는 태양광발전 연계 해수담수화시스템을 설치하였다. 이는 본 사업이 목표한 수경재배 시스템 100 가구 및 10 톤 /일의 해수담수화 시스템을 보급 및 이용하고자 한 정량적 성과를 달성한 것이다.

만족도 조사에서 수혜 가정들은 배추, 콩 등의 다양한 채 소를 재배하고 평균 $100 \mathrm{~kg}$ 회를 수확하여, 자가소비 또는 이웃 공유 뿐 아니라 잉여분의 판매까지 이루어져 협회의 자활사업 및 지역경제 산업으로 성장 가능성이 있음을 알 수 있었다.

응답자의 $85 \%$ 이상이 만족한다고 응답하여 수경재배 $\mathrm{ODA}$ 에 대한 만족도가 상당히 높음을 알 수 있었다. 응답 자의 약 $92 \%$ 는 신선 채소의 부족에 대한 태평양 도서지역 의 사회적 문제를 완화하기 위하여 다른 지역 및 다른 도 서에도 보급확산을 권장하였다.

이를 바탕으로 키리바시 SSUA협회는 기술지도 및 모종, 비료 판매, 야채 생산 등을 사회적 기업형태로 추진해 나가 
고, 마을 공동체는 '마을위원회'를 구성하여 이용 및 관리 를 체계화하는 등의 노력을 지속하고 있다.

향후, 본ODA 사업을 통해 구축된 수경재배시스템과 태 양광발전 연계 해수담수화시스템이 키리바시 타라와의 지 속가능발전(목표\# 2, 6 \& 7)에 기여하고, 다른 태평양 도서 국가로도 보급되어 해수플랜트 기반ODA사업으로 확산되 기를 기대한다.

\section{Acknowledgements}

본 논문은 해양수산부가 시행한 해양수산 $\mathrm{ODA}$ 사업인 "키리바시 해수를 이용한 식수 및 식량생산 시스템 구축 (GS4130)" 및 해양수산부 국가R\&D사업인 " $1 \mathrm{MW}$ 급 해수온 도차발전 실증플랜트 개발(PMS4730)"의 지원에 의해 수행 되었습니다.

\section{References}

Choi, M. Y., Kim, Y. S., Ji, H., Lee, H. S., Moon, D. S. and Kim, H. J. (2020). Application of Seawater Plant Technology for supporting the Achievement of SDGs in Tarawa, Kiribati, International Conference on Science \& Technology ODA 2020, Academic Society for Appropriate Technology, pp. 130131.

Kim, H. J., Moon, D. S., Lee, H. S. and Lee, K. H. (2018). Sustainable Seawater Utilization Academy (SSUA) for empowering capacity to achieve SDGs in SIDs, International Conference on Science \& Technology ODA 2018, Academic Society for Appropriate Technology, pp. 134.
Kim, H. J. (2021). Use of Marine Energy and Resources in Pacific Island Countries: Focused on Kiribati, White Paper on International Fisheries Cooperation (Networking-Past and Future of International Cooperation in Marine Fisheries); Korea Institute of Maritime Affairs and Fisheries: Busan, Korea, pp. 142157.

Korea Research Institute of Ships \& Ocean Engineering (KRISO). (2018). 키리바시 해수를 이용한 식수 및 식량생산 시스템 지원사업, BSPGS3520-11416-6, Korea Research Institute of Ships \& Ocean Engineering

Korea Research Institute of Ships \& Ocean Engineering (KRISO). (2019). 키리바시 해수를 이용한 식수 및 식량생산 시스템 지원사업, BSPGS3880-11664-7, Korea Research Institute of Ships \& Ocean Engineering

Korea Research Institute of Ships \& Ocean Engineering (KRISO). (2020). 키리바시 해수를 이용한 식수 및 식량생산 시스템 구축, UCPGS4130-11978-7, Korea Research Institute of Ships \& Ocean Engineering.

Petterson, M. G., Kim, H. J., and Joel, J. C. (2021). Conserve and Sustainability Use the Oceans, Seas, and Marine Resources, Geosciences and the Sustainable Development Goals; Sustainable Development Goals Series; Springer: Berlin/Heidelberg, Germany. pp. 339-367.

Petterson, S. M. and H. J. Kim (2020) Can Ocean Thermal Energy Conversion and Seawater Utilisation Assist Small Island Developing States? A Case Study of Kiribati, Pacific Islands Region. Ocean Thermal Energy Conversion (OTEC): Past, Present, and Progress. IntechOpen. 1-28.

https://en.wikipedia.org/wiki/Kiribati https://commons.wikimedia.org 